\title{
Politics of premature French claim of cure
}

THE French physician who claimed last week a dramatic improvement in patients with acquired immune deficiency syndrome (AIDS) when they were treated with the immunosuppressant cyclosporin A now says he was pressed into a premature press conference by an overenthusiastic minister.

"It wasn't our decision - it was the ministry of health's", said Dr Philippe Even of the Laennec Hospital in Paris. Dr Even agrees that the announcement of results after a week's trial with six patients, without controls, was "premature", but claims it was the pressure and the enthusiasm of health minister Mme Georgina Dufoix that led to the press conference. Dufoix appeared on television to claim this was "a great French discovery" that "bears the label of France".

Even is now following the line of his critics, saying that what is needed now is a full-scale trial. Ironically, it was his request to the ministry for help in setting up a trial that led to the widely-condemned public announcement.

Nevertheless, Even says, the treatment of his key patient, a 38-year-old man acutely ill with "end-stage" AIDS, has been "really dramatic". This person had been the most seriously ill of six patients treated, by last Friday, for nine days with the drug. The patient has shown a 100 -fold increase in the population of T-4 (Thelper) cells, the white blood cells specifically infected by the AIDS virus. Now the man has a T- 4 cell count of 400 per cubic millimetre, against 4 previously. Having been comatose and bed-ridden, he is now walking and feeding himself.

Dr Even also claims that "something very curious" happened during treatment indicating that cyclosporin $\mathrm{A}$ has a genuine effect. The patient, who had been taking cyclosporin orally got diarrhoea on the sixth day of treatment which interfered with absorption. His T-cell count immediately dropped, so that Even and his colleagues Jean-Marie Andrieu and Alain Venet decided to administer the drug intravenously. "Immediately his Tcell count rose again", says Even.

The five other patients, all less acutely affected, had shown at least a doubling in $\mathrm{T}$-cell count since treatment to levels of more than 300 per cubic millimetre (against a healthy level of some 7001,200 ).

Even's explanation is that cyclosporin A halts the activation of T -4 cells but does not inhibit the production of new T-4 cells by the bone marrow and the thymus gland. The result, says Even, is that mature T-4 cells can be held in check while the immune system regenerates itself. Even says that the activation of T-4 cells is "pivotal" in the replication of AIDS virus and the development of the disease; he speculates that an occasional course of cyclosporin A might keep the disease in check or even, with luck, eliminate it.

Outside France, AIDS clinicians say that the premature release of results was not only improper but cruel; "some of our patients will clutch at anything". There is also a fear that cyclosporin A could in the long run actually exacerbate the disease. According to one leading immunologist, the drug alone mimics the immunosuppressive effects of AIDS itself. There are also cases of AIDS-antibody-positive renal transplant patients who were put on immunosuppressants subsequently developing more acute AIDS than patients who had not been immunosuppressed, it is pointed out in London.

Moreover, the rise in T-4 cell count seen in Paris appears too rapid to be explained by regeneration of lymphocytes by the bone marrow, a process that might be expected to take 3-4 weeks, rather than just nine days. Further, the cerebral infections seen in AIDS patients, perhaps mimicking the infections of sheep by visna virus, may be resistant to cyclosporin $A$, London immunologists point out. The target cells for the HTLV-III/LAV virus of AIDS in the brain have not yet been identified, and may not been controlled by cyclosporin $\mathrm{A}$ even if it crosses the blood/brain barrier.

But Dr Even says that not one in five of the population of new T-cells in the patient's blood is an immature T-6 cell from the thymus, indicating that cyclosporin $\mathrm{A}$ has stimulated the production of new lymphocytes, at least from the thymus gland.

The next step, says Even, will be the setting up of a multi-centre trial of cyclosporin $\mathbf{A}$ in acute patients in France and, later, of an international trial. The pharmaceuticals company Sandoz, which makes and markets cyclosporin A, is convening an international conference on 8 November at its Basle headquarters in Switzerland, to prepare just such an international trial. But the only North American delegates attending will be Canadian, Even says. So far there are no delegates from the United States, and therefore no apparent US interest in joining in a trial. "That is their decision", Even says.

Robert Walgate

SDI

\section{Star wars critics criticized}

Washington

THE US Congress's Office of Technology Assessment (OTA), no stranger to controversy over President Reagan's Strategic Defense Initiative (SDI), has run into yet another dispute on the subject. Dr Robert Jastrow, an independent authority on missile defence, and $\mathrm{Dr}$ Frederick Seitz, chairman of the Defense Science Board, last week protested that the majority of an OTA advisory panel that supervised a recent OTA report* on SDI (see Nature 26 September, p. 276) were "strongly opposed" to SDI, and that OTA staff were biased against the project.

One of Jastrow and Seitz's chief complaints is that the OTA advisory panel, of which Seitz was a member, did not vote to endorse the report, and that there was no outside review. OTA's report concluded that SDI will increase national security only if the project achieves great technical success and if the Soviet Union cooperates in a negotiated arms reduction. Peter Sharfman, OTA's international security programme manager, replies to the criticism by pointing out that OTA's advisory panels never vote on staff reports and that their function is to provide independent review.

The Jastrow/Seitz attack on OTA was made at a briefing held by the Heritage Foundation, a conservative think-tank with strong links with the Reagan adminis- tration. Seitz was recruited to the advisory panel after General Daniel Graham, a strong advocate of SDI, had resigned, also alleging bias. Sharfman rejects categorically the charge that a majority of the panel were "strongly opposed" to SDI, and denies the suggestion that OTA staff were stretched beyond their limits.

Apart from the procedural issues, Seitz and Jastrow say that OTA failed to take account of numerous technical advances in missile defence in the past year. In their view, progress has been so encouraging that key demonstrations of SDI technology might be feasible 10 years sooner than was expected, with deployment possible during the 1990s. Among the advances named are the free electron laser, electromagnetic railguns and a new type of rocket engine, SCRAMJET.

OTA replies that it was familiar with the technological advances but avoided giving performance details because they are classified; all the technologies mentioned by Seitz and Jastrow, excluding SCRAMJET, are described in the OTA report. And in reply to a criticism that OTA overestimated the effectiveness of Soviet countermeasures, OTA says it regrets that specific technical objections were not raised by the advisory panel before the report's publication.

Tim Beardsley

-Ballistic Missile Defense Technologies. Office of Technolog! Assessment, 1985. 